\title{
Tangential Points: Aleksandr Bogdanov and Sergei Eisenstein Revisited
}

\author{
PIA TIKKA \\ Enactive Virtuality Lab, Baltic Film, Media and Arts School, Tallinn University, Estona; e-mail: pia.tikka@tlu.ee \\ Commentaries by STEVE F. ANDERSON and NADEZDA GRIGORYEVA
}

\begin{abstract}
Keywords: Eisenstein, Bogdanov, Tektology, systems thinking, life-building, naturalizing
In the newly founded Soviet Union, Aleksandr A. Bogdanov and Segei M. Eisenstein, each in his own way, struggled to make sense of the world by means of the most recent findings in the sciences. Both were driven by a desire to describe the universal laws of organization that would embrace the dynamics of the human mind and society, mutually, in arts and sciences. Bogdanov, a leading theoretician of political, economical, cultural, and educational revolution, is today also recognized internationally as one of the pioneering systems scientists of the early twentieth century. Eisenstein began to establish an international reputation thanks to the originality of his films and his eclectic theoretical writings that have remained a rich source of continuing discoveries for film scholars. I propose that both of these thinkers, in their own right, and by way of their common synergy, can contribute to a systemic understanding of today's complex world and its cultural reflections.
\end{abstract}

\section{Introduction}

In my early writings, especially my book Enactive Cinema: Simulatorium Eisensteinense (2008) and my book chapter'Tracing Tektology in Eisenstein's Holistic Thinking' in Alexander Bogdanov Revisited (2009), I put forward the hypothesis that Eisenstein's later montage theoretical ideas had to be influenced by Bogdanov's systemic ideas that he cultivated as one of the principal ideologists in the Proletkult, an educational institution created for the working class in 1917. To the best of knowledge at the time no scholarly effort had been invested in seeking possible intellectual linkages between Bogdanov and Eisenstein.

Many studies on Bogdanov's role in the Proletkult have focused mainly on its cultural and artistic activities (Mally 1990: xxii). Similarly, Eisenstein's relation to the Proletkult has also been discussed mainly in terms of his artistic activities. I believe that I was one of the first (Tikka 2008, 2009) to associate the development of Eisenstein's montage thinking with Bogdanov's ideas of systemic organization.

However intriguing it might be to tie these two intellectual theoreticians together, the task may be rendered impossible, owing to Eisenstein's well-known eclectic all-embracing syntheses of arts and sciences, and also given the systematic practice of concealment of sources in Eisenstein's writing. 
Whether Bogdanov was influenced by Eisenstein's artistic works is similarly unclear, as there are, to my current knowledge, no mentions of Eisenstein in Bogdanov's texts.

Even so, pursuing my original hypothesis, in this article I return to the heritage of these thinkers in the twenty-first-century scientific endeavour and relate them to the contemporary systemic and holistic approach to the human mind.

\section{Historico-political Contextualization of Eisenstein}

The personal archives of Sergei Eisenstein are a treasure trove for today's researchers. Eisenstein left a vast quantity of published and unfinished essays, scripts, films, book projects, drawings, cartoons, notes, and newspaper and magazine clippings spiced with eccentric humour and paradoxes (Bohn 2003; Nesbet 2003; Bulgakowa 1998). Anything that he found intellectually stimulating for his figurative thinking, as he terms his cinematic method, he made a note of. His eclectic approach is exemplified in his texts. He continuously refers to the works of art of others, on one hand, and to scientific writings, on the other, freely juxtaposing and extrapolating these. In many cases, his influences could be historically or disciplinarily distant from each other. Eisenstein was a master of adaptation, integrating any type of cultural objects of interest, no matter verbal or visual, to his constructive purposes (Bohn 2003: 248 n. 4).

Given the conditions of censorship and the tendentious nature of much publishing during the Soviet period, one cannot always be certain that the sources referred to in Eisenstein's publications correspond to his manuscripts. Sometimes, references to the original sources of inspiration or information may even be omitted completely. Sources were often disguised so that texts referred to only officially tolerated sources. For example, in Eisenstein's later writings, all pointers to Freudian psychoanalysis were hidden behind reflexological concepts (cf. Bohn 2003: 66-67), while in the twenties Eisenstein had publicly discussed his objective as being 'to integrate Freud's and Pavlov's doctrines' (Bordwell 1993: 116 n. 1).

The continuous stream of new publications on Eisenstein approves that his writings and films are an inexhaustible well of inspiration for researchers (e.g. Christie and Vassilieva 2012). Eisenstein has been mainly associated with the modernist framework of constructivism, futurism, suprematism, and symbolism, together with the eccentric theatre practices, such as the Factory of Eccentric Actors (FEKS), or biomechanics as applied to actor training by Vsevolod Meyerhold. Eisenstein's views on film history, aesthetics, anthropology, and psychology have been extensively studied (see e.g. Bordwell 1993; Bulgkowa 1998; Bohn 2003; Olenina 2020; and Somaini 2011).

While it has been recognized that the contemporary scientific discoveries influenced the theoretical evolution of Eisenstein's montage thinking from the more mechanistic constructions to his elaborated organic-dynamic systems, I found the only hint of a linkage between Eisenstein and Bogdanov in film studies in David Bordwell's book The Cinema of Eisenstein (1993: 35-37, 135-136; Tikka 2008: 69). Eisenstein's systemicity, I argue, is inherent in all his thinking. We now know that the emerging Soviet cybernetic structuralism of the 1960s pointed to Eisenstein's cinematic work as a forerunner of later studies on systems of signs (cf. Bordwell 1993: 261; Segal 1974: P1. 23; Ivanov 1976). It has been noted that, unlike West European semiotics, the paradigm of Marxist semiotics was more congenial to Eisenstein's theoretical interests. Both embraced a wider academic tradition including such paradigms of'cultural (social, structural) anthropology, social psychology, historical ethnography, content analysis, poetics, and art criticism' (Segal 1973 in Grossi 1999: 173; Segal 1974: P1. 2). It also seems that the Russian-speaking research community previously neglected inquiring into Bogdanov's possible theoretical influence upon Eisenstein's theoretical thinking, a task taken up by the scholars of this Issue. 


\section{Exploring the Influence of Bogdanov}

The Proletarian Cultural and Educational Organization (1917-1932), referred to as the Proletkult, provided the young Russian film director and theoretician Sergei M. Eisenstein with a valuable working framework. Lynn Mally, in her Culture of the Future: The Proletkult Movement in Revolutionary Russia, describes the Proletkult as'a complicated social and cultural movement with many conflicting programs' (1990: xxiv). One of the intellectual initiators of Proletkult's educational programme was the medical doctor and Marxist theorist Alexander A. Bogdanov, who held that 'proletarian science' offered the only means of constructing a sustainable socialist system (Bogdanov 1918/1924; in Mally 1990: 162).

By 1920, when Eisenstein joined the Moscow theatre section of the Prolekult, the originally autonomous institution had been placed, at the behest of Lenin, under the jurisdiction of the People's Commissariat for Enlightenment (Narkompros) in charge of general cultural and educational policy. Bogdanov had distanced himself from the organization in order to spare it political embarrassment (White 2018: 153). Following his death in 1928, Bogdanov ceased to be published in the Soviet Union and his writings in philosophy, economics, sociology, and culture were deemed, from the point of view of 'orthodox' Marxism, to be heretical (see Oittinen 2021).

IImari Susiluoto, in his pioneering 1982 publication The Origins and Development of Systems Thinking in the Soviet Union: Political and Philosophical Controversies from Bogdanov and Bukharin to Present-Day Re-evaluations, identified Bogdanov as a precursor of cybernetics and general systems theory, as elaborated in the works of Norbert Wiener (1948) and Ludwig von Bertalanffy (1968), respectively. This claim was endorsed in a later collection of essays Alexander Bogdanov and the Origins of Systems Thinking in Russia (Biggart et al. 1998). Together with George Gorelik's translation Bogdanov's Essays in Tektology: The General Science of Organization (1980), these works have served in this essay as the principal sources for the understanding of Bogdanov's place in Soviet scientific and cultural history.

Bogdanov published his Tektologiia (Vols. I-III) between 1913 and 1922. For him, tektology represented 'not a leap in scientific evolution, but a necessary conclusion from the past, the necessary continuation of what has been done and is being done by men in their practice and theory' (Bogdanov 1912/1980: xiv). His main objective was to unify'the organizational experience of mankind'by describing its governing universal 'organizational principles'(Bogdanov 1912/1980: xiii). These principles would govern the 'dynamic equilibrium of changes' in terms of 'a practically relative equality of the two processes of assimilation and disassimilation' that oscillate in all organic and non-organic things, and allow explaining the emergence of both individual psyche and social consciousness (ibid.: 78-79).

According to Gorelik's introduction to Essays in Tektology, Bogdanov's philosophical ideas were criticized by many Marxist philosophers and did not find a wider audience (Gorelik 1980: iii). This may have been the case outside of the Proletkult movement, but amongst the artists and intellectuals associated with the Proletkult, Bogdanov's ideas were widely circulated and appreciated (Susiluoto 1985: 67). During 1918-1921, as a professor of political economy, Bogdanov lectured regularly at Moscow State University (Popkov 1998) and his ideas reached more than a million workers through the journal Proletarskaja kultura (Susiluoto 1982: 67). Bogdanov also revised new editions of the three parts of the Tektologiia before his death in 1928 (Gorelik 1980: ii). A German translation was available in Berlin between 1926 and 1928 (Biggart et al. 1998: 333-341). New editions were published of Bogdanov's other works, such as Between a Man and Machine (1918) and his science-fiction novels Red Star (1908-1928) and The Engineer Menni (1912-1925).

In response to Bogdanov's influence in the Proletkult and other educational institutions, Lenin wrote in Pravda, 1 December 1921, thus: 'Behind the mask of proletarian culture, workers are being offered bourgeois opinions in the realm of philosophy (Machism) and silly, depraved, degenerate tastes in the realm of art (Futurism)' (cited in Bulgakowa 1998: 32). However, despite increasing political pressure from the Communist Party, according to Alekseeva, the scientific world of the 1920s 
and 1930s continued to apply Bogdanov's organizational principles. 'When it came to founding such ideological centers as the Institute of Marxism-Leninism, the Lenin Institute, the Institute of Red Professors, the Workers'Faculties, the Communist Universities or the Higher Party Schools, the ruling elite of the 1920s and 1930s was guided by organizational principles derived from the work of Bogdanov' (Alekseeva 1998: 102).

According to Alexander Ogurtsov, Bogdanov himself pointed out that tektology in its embryonic form had been applied, for example, in analysis of the principles of organization by Platon Kerzhentsev and Sergei Chakhotin and in the psycho-technics of labour power by Isaak Shpilrein (Ogurtrsov 1998: 262). As Director of the Institute for the History of Science and Technology, Nikolai Bukharin constantly made use of Bogdanov's ideas without referring to him; Bogdanov's ideological collaborator Anatolii Vasilievich Lunacharsky (1875-1933), who was Commissar of Enlightenment (Narkompros) in the first Soviet government until 1929, also made use of Bogdanov's ideas, and did so openly (Alekseeva 1998: 101).

Considering Bogdanov's contributions to his contemporary intellectual environment and the Proletkult, including those that are widely acknowledged and those that are lost or hidden, it seems plausible to assume that he exerted some influence on the intellectually voracious twenty-year-old engineering student and revolutionary artist Eisenstein (see Bulgakowa and Biggart 2021).

\section{The Euphoria of Life-Building}

In the early twenties, the art of cinema had been endorsed by the leader of the Communist Party, Vladimir Lenin, as one of the principal instruments for educating the working masses in new socialist class-consciousness and in the construction of a New Soviet Man. Lenin expected the cinema to highlight the emotionally powerful contrasts between the former misery of working people and their future well-being, and Eisenstein responded to this revolutionary challenge (Bordwell 1993: 2-3). Eisenstein believed that his montage method would serve as a powerful instrument for educating the Soviet, and eventually global, proletariat. It would help the proletariat firstly to become aware of its own power, and secondly to realize how to reach a higher level of unity and social consciousness. This educational mission was compatible with the socio-political objectives of the Proletkult.

In his essay 'How I Became a Director' (1945), Eisenstein recalled the 'ecstasy of the epoch' (Eisenstein 1996: 289). The ideological, intellectual euphoria of the period transformed the New Soviet Land into a melting pot of the latest discoveries in natural, social, and economic sciences, as portrayed, for example, by Emma Widdis, in her Visions of a New Land: Soviet Film from the Revolution to the Second World War (2003). ${ }^{2}$ At a time when the Soviet government dreamed of attaining Western levels of industrialization, economic growth, and social well-being, the ideas of Frederick W. Taylor's The Principles of Scientific Management (1911) were in vogue (Susiluoto 1982: 106).

In her essay 'The Stofflichkeit of the Universe: Alexander Bogdanov and the Soviet Avant-Garde' Maria Chehonadskih emphasises that '[a]ny kind of social practice is the labor of organization, or the labor of world-building' (2018: n.16). As Simona Poustilnik points out, the 'conceptions of "assembling" similar to those expressed in [Bogdanov's] Tektology provided Constructivists with a scientific rationale, projects and terminology for their experiments in a new "production art"' (see Poustilnik 2021). Many of the keywords of the intellectual and artistic discourse of this period associated with this techno-scientific enthusiasm, for example 'energetics', 'life-building,', 'psycho-engineering', urbanism,

$1 \quad$ Lunacharsky was head of the committee that decided that Eisenstein would be allowed to direct The Battleship Potemkin (1925) to celebrate the 1905 events (Bulgakowa 1998: 56).

2 Though she discusses early Soviet economic planning, Widdis does not mention the systems thinking of Bogdanov or Bukharin, but instead, refers to American 'flow diagrams' of production (2003: 57). 
ions, electrons, neutrons, thermodynamics, calculations, and with the idea of labour as a creative force. These concepts were widely applied in collaboration between scientists and artists of the Russian Modernist movement, as Lev Manovich has shown in The Engineering of Vision from Constructivism to Computer (1993).

Many of Eisenstein's friends, constructivist artists, and other intellectuals in the Proletkult and groupings such as the Left Front of Art (LEF), or the Russian Formalists, also saw education as a method for constructing social consciousness. The poet and Taylorist Aleksei Gastev, author of the important 'Scientific Organization of Work', coined the term 'social engineering' (Bordwell 1993: 35, 37; Widdis 2003: 57; see also Golomstock Totalitarian Art 1990, in Manovich 1993: 22). Inspired by thermodynamics, the constructivist theorist Aleksei Gan, founder of the first Soviet film journal Kinofot (1922), based his 'Tectonics' upon the idea of'fluidity [tekuchest] as an expression of the workers' active social force' (Gan 1922: 56; in Widdis 2003: 60, 208 n. 5). Cinema represents 'a conscious extension of the proletarian state', argued Gan in his 1928 essay 'Constructivism in Cinema' (Bann 1974: 130; Petric 1987: 13, 15). A close friend and collaborator of Eisenstein, Sergei Tretiakov, described artists as 'psycho-engineers' and art as a method for organizing 'the human psyche through the emotions' (Tretiakov 1923: 202; in Manovich 1993: 22; Bordwell 1993: 5, 116, 136). Thinking along the same lines, Dziga Vertov elaborated his method of a pure perception-based cinema, conceived of 'dynamic geometry, a succession of dots, lines, planes, and volumes, as movement of pure form in an organized space that consciously made use of rhythm' (Bulgakowa 1998: 36). The symbolist Andrei Belyi discerned 'prosodic patterns of minute detail, generating tables and graphs through which he hoped to discover poetic laws and to found an empirical science of literary form' (Bordwell 1993: 35).

It seems that Bogdanov's ideas were relatively widely applied by scientists and managers, 'to the reconstruction of industrial output, of scientific work, and of the arts, whose function was deemed to be the production of artistic values' (Ogurtsov 1998: 263; see also Chehonadskih 2018). However, not all techne-oriented practices of the era were systemic in the dynamical sense of Bogdanov's universal organizational science. In Between Man and Machine, published in 1918, Bogdanov expressed his concern at Gastev's mechanistic application of Taylor's ideas to the organization of work and suggested that the more organic method was to be discovered in the complex realm of life forms (Bogdanov 1918: 15; Susiluoto 1982: 106-107). Also, Alexander Rodchenko seemed to understand the term organization in a more mechanical way: 'A construction is an objective or a task performed according to a particular system, for which particular materials have been organized and worked in a manner corresponding to their inherent characteristics' (Rodchenko 1921: 60). As Bordwell points out, the constructivists' interest in 'the demands of the material' set their ideas apart from those of Bogdanov (Bordwell 1993: 35). In 1923, Lunacharsky, articulating an educational point of view that he shared with Bogdanov, criticized the more simplistic psycho-engineering practices of the constructivist artists of only playing at being engineers without any deeper understanding of the systemic essence of the machinery (Taylor 1991: 177).

It is difficult to estimate how far Bogdanov's ideas influenced the intellectual environment of the young Eisenstein, but it seems unlikely that he could have been unaware of them. Bogdanov's principles of organizing the forces of production and developing comradely social relations were applied across a whole spectrum of artistic, intellectual, and scientific effort in 'life-building' (Widdis 2003: 207 n. 99; Susiluoto 1982: 29). ${ }^{3}$

3 The term 'life-building' [zhiznestroenie] was coined in 1923 by Nikolai Chuzhak in his article "How to Perceive Today's Art" (Widdis 2003: 207 n. 99; Susiluoto 1982: 29). 


\section{Eisenstein in the Proletkult}

During his years in the Proletkult from 1920 to 1925, Eisenstein appears to have been driven by a passion for scientific paradigms that could contribute to his artistic methods. In 1920 he attended a film workshop run by Lev Kuleshov, in which the notion of montage was introduced to Soviet cinema. The montage method would generate new meanings through the juxtaposition of different film shots ('the Kuleshov effect'). Vsevolod Meyerhold's classes in direction introduced Eisenstein to biomechanics, which drew upon the mechanistic organizational principles of Taylorism. According to Meyerhold, an artist is always also an engineer, while an actor's performance is both a product and an instrument for organizing the well-being of society (Meyerhold 1981: 103-104).

Eisenstein soon initiated his own Laboratory for Modeling New Behavioral Norms together with the constructivist theoretician Boris Arvatov, and collaborated in the Moscow Proletkult production The Mexican in 1921 (Bulgakowa 1998: 44; Bordwell 1993: 3). In 1922, he became the director of the Proletkult's travelling theatre company, co-operating also with the FEKS (the Factory of Eccentric Actors) in Petrograd (Bulgakowa 1998: 234-235). Eisenstein's eccentric theatre sketch Enough Simplicity for Every Wise Man included his first piece of film, Glumov's Diary (1923) (Aumont 1987: 43). In 1924, Eisenstein's Proletkult theatre production Gas Masks premiered in a real working factory in Moscow.

These theatrical experiments in the Proletkult context resulted in Eisenstein's manifesto of 'montage of attractions' (1923/1924), a cinematic system where any phenomenon as a whole is constituted on a complex interaction of its integral parts. The young Eisenstein viewed the organization of montage attractions as a kind of miniature model, in which people, objects, and themes comprise a multiplicity of features, involving an interplay of conflicting or opposing moral, emotional, or perceptual forces. The features that make someone appear, for example, 'noble' are dissolved into other features such as erotic behaviour, hinting at morally ambivalent attributes of the character (Eisenstein 1988: 33-38). Eisenstein's work in the Proletkult revealed his fascination with the reciprocal interaction between 'external' expressive movements and 'internal' physiological stimulation of the senses, which lasted throughout his life.

The correspondence between Eisenstein and Valerian Pletnev of the Executive Bureau of Moscow Proletkult, published in the journal Kinonedelia, reveals how his relationship with the Proletkult ended following a disagreement over the authorship credits for Strike (Eisenstein 2006: 3-10). According to the Director of the Eisenstein Museum Naum Kleiman (2007), Eisenstein was not interested in politics, and his break with the Proletkult may have been owing more to professional than to political considerations. He was not alone in his exasperation with the leadership of the Proletkult: in his response published in Kinonedelia (1925, No. 10) he refers to a group of fellow artists of the Proletkult Theatre who had resigned at the same time as himself (Eisenstein 2006: 7).

Despite these final political conflicts, the Proletkult provided an important intellectual haven for Eisenstein's early scientific experiments and his studies on organization of montage as an expressive formulation of human cognition. In 'Montage of Film Attractions' (1924), he boldly stated what he thought was his own contribution to physiological studies:

The norms of organicism (the laws of organic process and mechanical interaction) for motor processes have been established partly by French and German theoreticians of movement (investigating kinetics in order to establish motor primitives) and partly by me (kinetics in its application to complex expressive movements - and dynamics of both: see below) in my laboratory work at the Proletkult Theatre. (Eisenstein 1988: 51)

As noted by Inga Pollmann: 'Eisenstein increasingly shifted the focus from a confrontational model of montage - a montage of shocks and "simple" dialectical oppositions - to a more complex, integrated, organic model /.../ 'a conception of film structure as mimicking organic structure' (2018: 93). 
Under Stalin's regime, Eisenstein experienced his share of political pressure. During the years when Eisenstein was acquiring international fame with his films Strike (1925), Potemkin (1925), October (1928), and The Old and the New (1929), the Russian Formalists by whom he had also been influenced, were subjected to repeated political attacks by the Communist Party. The Formalist school disappeared from the cultural scene during the late 1920s, around the same time as the Proletkult. Eisenstein was also later attacked for his ideas of 'montage as a method' and the proletarian masses as the main character in his early films. In 1933, Eisenstein replied to this criticism. In 'An Attack by Class Allies' (1933) he defended his montage theory against accusations of'reactionary formalism' (Eisenstein 1988: 261-275).

According to Marie Seton's account in her Sergei M. Eisenstein: A Biography (Seton 1978: 340-341), the head of the Institute of Scientific Cinematographic Research, Nikolai Lebedev, criticized Eisenstein for being involved with 'the theories of Freud, Marinetti [the Futurist], Pavlov, the physiologist, Bogdanov of the Proletcult and many bourgeois psychologists and philologists' (1978: 340). In 1935, at the All-Union Creative Conference for Soviet Filmworkers, Eisenstein's position as a Marxist artist and dialectical theoretician was re-evaluated. Lebedev remarked that Eisenstein began studying Marxism only after returning from his excursion in Hollywood and Mexico during 1929-1932, and that it was 'only now that we can speak of him as a theoretician, who has mastered the methods of Marxism' (ibid.).

In retrospect, many Eisenstein researchers may find themselves agreeing with Jacques Aumont, who maintained that, notwithstanding occasional superficial accommodation at the conceptual level, under the pressure of political circumstances, Eisenstein's lifelong theoretical project displays consistency and unity that are not to be confused with adaptation to changes in Marxist-Leninist ideology (Aumont 1987: 67, 146, 199). At the same time, Eisenstein being linked publicly to Bogdanov carried considerable risk. Many theoreticians who had adopted Bogdanovist systems thinking were executed (see Susiluoto 2006: 94-95). The disappearances and public trials of politicians and figures from the cultural world were noted in the international media. In December 1936, the French Cinémonde cried out, 'Is Eisenstein in prison?' (Bulgakowa 1998: 187). Despite the hostility that he encountered during the 1930s from the cultural establishment that put his film career on hold, Eisenstein continued with his explorations in theory.

\section{Eisenstein's Theory Formation Meets Bogdanov's Organization Science}

Eisenstein's departure from the Proletkult should not be understood as an abandonment of systemic ideas, some of which he may have borrowed from Bogdanov. Rather, he continued to explore the systemic conceptualizations of dynamic organization in artistic creation. Gradually his interests shifted from the artistic domain to the domain of scientific discoveries in physics, psychology, and biology. His writings turned from Pavlovian reflexology and mechanical shock montage towards cinematic montage of the 1930s and 1940s as a method - equivalent or even superior to any scientific tool for analyzing and describing the holistic synthesis of human experience (see Bulgakowa, \#this Issue). This preoccupation remained at the core of his thinking in later years, for example as expressed in Nonindifferent Nature: Film and the Structure of the Things (1987).

As has been pointed out by Ilmari Susiluoto and by Nikita Moiseev in his essay'Tektology in Contemporary Perspective' (see Susiluoto 1982: 26; Moiseev 1998: 221), systems thinking was spreading widely in Europe during the first decades of the twentieth century. Non-mathematical in orientation, systems thinking converged with the main ideas of the emerging disciplines of psychology and biology. It was influenced by Darwinism and in particular with the neo-Kantian 'organicism' as described in Ernst Cassirer's The Problem of Knowledge: Philosophy, Science, and History since Hegel (1950). 
As a Marxist, Bogdanov sought to dispense with Hegelian dialectics and devise a new holistic systems theory consistent with the latest findings of science. As James White notes in'Sources and Precursors of Bogdanov's Tektology', the intellectual influences of Bogdanov are difficult to track because he 'seldom identifies any particular writer as the inspiration for any given idea' (White 1998: 27). However, Bogdanov does acknowledge the post-Darwinian psychological and physiological research of the nineteenth century, for instance, that of Haeckel, Mach, Spencer, von Helmholtz, Wundt, von Ehrenfels, James, Le Dantec, Timiryazev, and Babukhin (see Glovelli 1998a: 43-44; Biggart et al. 1998: 106-107, 201).

In 1929, Eisenstein's diary recognized three points of interest:'Dialectics, Reflexology, Freud'(Eisenstein RGALI 1923-2-1114.62, in Bohn 2003: 65). Freud's psychoanalytic texts and Jung's Psychological Types: or, The Psychology of Individuation (1923) were among the sources of inspiration that Bogdanov shared with Eisenstein. According to Bohn, the influence of psychoanalysis lingered in Eisenstein's aesthetic ideas about the spiral structure of progression and regression further developed in his theoretical projects Grundproblem and Method (Bohn 2003: 161). ${ }^{4}$ According to his 1932-1933 diary, Eisenstein decided to change, for the purpose of camouflage, his theoretical construction of 'art as regression'to that of 'art as synthesis': 'instead of regression, regression of components, or spiral movements' (RGALI 1923-2-231, 5; in Bohn 2003: 110-111;Tikka 2008: 110). While Eisenstein's treatment of progression and regression has been linked to his interest in the psychoanalytical ideas of Freud and Otto Rank (e.g. Bordwell 1993), however, these concepts may also be related to the contemporary ideas in life-sciences in general, and in particular to the tektological dynamics described as 'periodic oscillation /.../ almost all of the life processes are of the periodic oscillating type. Such are the pulse and breathing, work and rest, and the vigilance and sleep of organisms' (Bogdanov 1980: 9). In psychology, Gestalt theory, with its emphasis on holism and the dynamical aspects of perception and cognitive construction, provided another important framework. The Gestalt principle of a whole being greater than the sum of its parts was openly adopted by Eisenstein (1943: 17). It had also been a core principle of Bogdanov's tektology since 1913 (Bogdanov 1980: 38).

While Bogdanov has mainly been portrayed as a social theorist and systems thinker, he also practised psychiatry and served as a doctor during the First World War. In 1926 he founded an experimental Institute of Blood Transfusion in Moscow. Gloveli's essay 'Psychological Applications of Tektology' highlights Bogdanov's interests in the predominance of pleasure and pain in the human psyche, a selective orientation towards the hedonic aspect of life, 'characterology' (the science of handwriting), and 'thanatology' (the science of death) (Gloveli 1998: 88-9.).

Eisenstein's theoretical views have been associated with dialectics (e.g. Luka 2018: 194-198). However, instead of adopting Hegelian dialectics as his methodological principle, Eisenstein preferred to use his own 'reversed' notion of material dialectics. In this he displayed an affinity with Bogdanov, for whom the 'old' Hegelian dialectics was 'not sufficiently dynamic and in its naked formalism leaves unexplained the general mechanism of evolution' (Bogdanov 1980: 277). While Eisenstein often applied the notion of conflict, he seemed to understand the term as constituting the internal organizational dynamics of the wholeness of the complex theme or phenomenon under scrutiny, rather than emphasizing the struggle as a force for unidirectional progress.

According to James White, Bogdanov's key concepts remained relatively constant throughout his lifelong theoretical development (1989: 103). He viewed religious experiences as the basis for customs and rules in earlier societies, drawing upon the theories of anthropologist Ludwig Noire and of Max Müller on natural mythologies (Susiluoto 1982: 46 n. 3). A similar interest is evident in Eisenstein's mature essays (e.g. 'habit logic' and 'participation'), however, his sources seem to differ (e.g. Cassirer, Levy-Brühl, Bühler). According to V. V. Popkov (1998), the two thinkers make references to Darwin, Marx, James, and Spinoza. Both Eisenstein and Bogdanov were influenced by Goethe, 
'poet-encyclopaedist' and 'teacher of the creative process', on Bogdanov, 'who interpreted Faust as a metaphor for the striving of the human soul for a "harmonious integral life" devoted to work for the collective well-being of humanity' (Gloveli 1998a: 44).

Bogdanov, in On Proletarian Culture [O proletarskoy kul'ture. 1904-1924], emphasized that when building the proletarian culture, the past work of humanity should not be discarded but take into account'the classics of the world literature, such as Shakespeare, Balzac, Goethe, Schiller, Byron, Pushkin, Lermontov, Gogol, Nekrasov, Tolstoi, Gor'kii, Rynis, Verhaeren' (Bogdanov 1924: 168-170). Eisenstein, too, throughout his life, worked on the task of incorporating the older cultural inheritance into the revolutionary process. His texts repeatedly return to his hypothesis, which states that already the classical masters had applied the method of montage in organizing their narratives long before the technological invention of cinematography.

Like Bogdanov, Eisenstein saw himself as an organizer of mass consciousness, and a skillful educator of the workers. From his early idea of montage of attractions through to his mature notions of holistic montage during the 1930s and later years, Eisenstein equated montage composition with organizing the cognition of the spectators. In this light, the process of authoring cinema is not so much about creating a product as it is about authoring the unconscious dynamics of the cinematic experience.

According to Bogdanov's thinking, the systemic complexity of an organism, be it a psyche or a collective, is regulated by the dynamics of tektological selection that modify the earlier structures of the organism. The continuous interaction of the system with the surrounding environment generates a series of sequential layers, of which 'some layers were created earlier while others later "superimposed" themselves (in the organizational sense) on the earlier layers' (Bogdanov 1980: 285). In Eisenstein we find a similar notion, whereby a cinematic frame is superimposed on top of another in a manner in which the lower level of movement interacts with the highest intellectual stage of montage in a complex manner. The following citation indicates analogies between the thinking of Eisenstein and that of Bogdanov: '[T] he simultaneous movement of a number of motifs advances through a succession of sequences, each motif having its own rate of compositional progression, while being at the same time inseparable from the overall compositional progression as a whole' (Eisenstein 1991: 333).

Eisenstein envisioned a book format similar to contemporary hypertext, a sphere, where it would be possible 'to step from each contribution directly into another and to make apparent their interconnection ... in a synchronic manner of circulation and mutual penetration' (Eisenstein 1988a: 344; Bulgakova 1996: 31-108; 2021). Eisenstein's idea of a Spherical Book can be considered as one of his many mental models for organizing knowledge and experience into a single framework. Its relevance to present-day audiovisual media and to future virtual technologies is evident (see Waite 2021), even more so considering the idea of a hypothetical synthetic environment simulating the physical world referred to as metaverse (Lee et al. 2021: 1).

Just as Bogdanov formulated tektology as a method for studying the general organizational modes of any natural, social, or cognitive phenomena, ranging from inorganic structures to the death of an organism, so Eisenstein argued that montage as a method for organizing emotionally powerful experiences in arts, in fact, had a more profound function - as a method for discovering the general organizational laws of human psychology. In 'The Workers' Artistic Inheritance' (1924: n.d.), Bogdanov describes the problem of creative organization thus: It is [a problem] in two senses: in the first it is a question of how to organise harmoniously a certain sum total of the elements of life and experience; in the second sense, it is a question of how to ensure that the unity created in this way may serve as a means of organisation for a certain community.' One can identify two key questions that were central to the enquiries of both Bogdanov and Eisenstein, both of which are paracronically relevant to the contemporary studies of the human mind: 1) how does the mind organize phenomena of life and experience into meaningful units that 2) can be collectively shared with others? The attribute of 
'parachronic' (outside of time) 'implies that a linear representation of history is regarded inadequate to describe the evolution of bio-cultural cognition, and particularly its apparent characteristics: sensemaking methods that recycle generation after generation' (Tikka 2008: 42).

Retrospectively, by combining socio-cultural ideas with the most recent findings of natural sciences both Eisenstein and Bogdanov engaged in what could be described as a holistic naturalizing programme of their times, paracronically comparative to that proposed in Naturalizing Phenomenology: Issues in Contemporary Phenomenology and Cognitive Sciences (Petitot et al. 1999). By juxtaposing phenomenological first-person inquiries with recent scientific views, Eisenstein's figurative imagery aimed beyond mere philosophical conceptualizations, towards establishing cinema as a method for naturalizing the phenomenal domain of embodied experience (Tikka 2008: 26). In Essays in Tektology, Bogdanov's first chapter 'What is Organizational Science?' calls for investigation of the complementary elements of the unity of organizational methods present 'in psychical and physical complexes, in living and dead nature, in the work of elemental forces and in the conscious activity of people' (1980: 10). When reading Bogdanov's description of the systemic dynamically fluctuating nature of living organism in interaction with its environment side-by-side with Autopoiesis and Cognition: The Realization of the Living (1980) by Humberto Maturana and Francisco Varela, the intellectual blood-line between these thinkers is indisputable. Both Eisenstein and Bogdanov aimed at describing universal principles of organization that embraced the human at its core in a dynamical interaction with its environment. When extrapolated to the twenty-first century, as in (Tikka 2008), both thinkers appear to have considered the human mind in terms similar to the theory of embodied, enactive mind postulated by Varela and colleagues (1991). That is, as being 1) governed by the biophysical laws of nature, 2 ) inseparably embedded in its dynamically changing socio-cultural environment, and 3) extending to the world in various ways, including through technologies such as cinema in their time, all by means of bi-directional complex enactment between the individual and the world.

\section{Conclusion}

Until recently, only a few researchers have emphasized the complex systematic and organizational orientation of Eisenstein's thinking. I have suggested parallels between Eisenstein's theory of montage and Bogdanov's application of tektological ideas to separate fields of sciences (Bogdanov 1980: xvi). Eisenstein insisted that his montage theory constituted not only the organizational principle of cinema but also that of the entire domain of the arts, and even that it expressed universal organizational laws that would govern not only the arts but also the sciences. According to his thinking, by studying cinematic form in particular, the more general organizational laws guiding the organic world and the human mind could be discovered.

My essay returned to the question of whether Bogdanov's systems thinking might have provided a framework for Eisenstein's mature thinking. It is difficult to prove direct influences given the absence of direct references in the work of Eisenstein to Bogdanov, or vice versa. Even so, there is evidence that the ideas of Bogdanov circulated widely in intellectual circles. Working in the Proletkult, Eisenstein could hardly have been unaware of his works. The political circumstances of the time also gave reason for some discretion concerning one's intellectual sources.

In 1921 Bogdanov predicted the future of his organizational science:'[l]n the history of the sciences there can be found quite a number of theories and hypotheses that became obsolete long ago, but which, nevertheless, can still serve as a valuable tektological material. In this sense, tektology will preserve and save for [humanity] much of its labour, crystallized in the verities of the past' (Bogdanov 1980: 166). Eisentein made a similar observation in 1935:'I should like to start by saying this: it is very 
curious that certain theories and viewpoints, the expression of scientific and theoretical knowledge in one historical period, lose their scientific value in the next; but they persist, possible and admissible not as science but as art and imagery' (Eisenstein 1996: 26).

A close examination of Eisenstein's later montage thinking in parallel with a close reading of Bogdanov's general science of organization could reveal similarities in their respective concepts of system thinking - perhaps even to the extent of borrowing (see Tikka 2008, 2009). Finding synergies and mutual references between the two theoretical Leviathans may seem to be an issue of mere academic curiosity. However, both Bogdanov, who elaborated his tektology until his death in 1928, and Eisenstein, who expressed similar ideas in his later montage theories from the 1930s until his death, deserve to be honoured as pioneers of the holistic dynamical systems approach within their specific fields. The preoccupations of Eisenstein and Bogdanov persist in the universal world-building of the twenty-first century, for example, in the synergies between their ideas and the envisioned 'metaverse'a commonly shared virtual ecology driven by universal principles of organization.

Parts of the paper were previously published in Alexander Bogdanov Revisited, Aleksanteri Series 1:2009, ed. V. Oittinen, 211-234. Helsinki: Gummerus.

The writing has been supported by the EU Mobilitas Pluss Top Researcher Grant MOBTT90.

\section{Art/Technology/Culture Commentary by Steve F. Anderson}

In her contribution to this volume, Pia Tikka builds on more than a decade of theoretical and historical work combined with experimental research at the intersection of cognitive neuroscience and creative practice. Tikka's work has contributed to defining, shaping and operationalizing key aspects of the field of neurocinematics, which uses real-time brain imaging to interpret viewers' responses to cinematic stimuli. Tikka has also helped bridge the divide between diagnostic science and creative practice in contexts where the 'artist' is too easily marginalized as a 'content provider' rather than a full participant in scientific study.

The foundation of her work includes a multi-part PhD dissertation comprising a book-length text published as Enactive Cinema: Simulatorium Eisensteinense, a short, narrative film titled Obsession, and an interactive viewing apparatus - an'Eisensteinian montage machine' - that uses viewer biofeedback to dynamically re-edit narrative elements of the film. I think it's reasonable to suppose, as Tikka also proposes, that had the technologies of fMRI (functional magnetic resonance imaging) and real-time editing engines been available in the early twentieth century, they would have been of great interest to Sergei Eisenstein and others invested in developing the language of cinema to suit the era's concurrent transformation of social and political relations.

In her dissertation published in 2008, Tikka noted the profound influence of Alexander Bogdanov's systems theory on Eisenstein's early development, as well as the vicissitudes of Soviet political pressures that kept this influence from being openly acknowledged. It is striking how long after de-Stalinization the proscription against fully recognizing Bogdanov's contributions appears to have lasted, even as his models for understanding relations between science and art; politics and culture; and social and technological structures have grown to seem eerily prescient. Bogdanov's universal science of organization, which he dubbed 'tektology', insists on understanding the world in terms of intersecting and interdependent systems, a conceptual model that resonates profoundly not only 
with the vast computational systems that surround us but with the ecological turn that is currently shaping much of contemporary cultural theory and art practice.

Tikka's work at the intersection of creative arts and technology may also be understood in relation to the industrial practice of world-building. Like Eisenstein's theory of montage, the principles of world-building have not been embraced in all sectors of the film and television industries. Among other disruptions to the assembly-line model that the film industry inherited from the Industrial Revolution, world-building rejects linear processes in favour of a holistic, systems-driven approach to narrative design. Rather than start with a script that articulates character, setting or genre, the world-building process might begin with defining a set of rules or limits for a story world along with the components of interlocking systems (social structures, technologies, belief systems, economics, etc.), from which any number of narrative instances might emerge. In the world-building workflow, production design or visual effects might be fully integrated and concurrent with the ideation and writing processes. Although not explicitly indebted to the aesthetics of databases and the transition from personal to networked computing, it is difficult to imagine the distributed and simultaneous production practices of world-building without these supporting technical infrastructures.

Tikka also notes the transitional role played by cybernetics theorists such as Norbert Wiener in the late 1940s, whose work could be suggested to build on Bogdanov's theory of tektology. Wiener's framing of cybernetics responded to the emergence of mainframe computing and its potential to extend human bodies and cognition with technology. Like tektology's relation to cinematic montage, cybernetics provided a model for understanding the relation between humans and machines that was both metaphorical and literal. Artistic experiments that were directly or indirectly indebted to cybernetics briefly flourished in conjunction with rapidly evolving technologies for computation in the 1960s. Best known are the Cybernetic Serendipity show that took place in 1968 at the Institute of Contemporary Arts in London and the Experiments in Art and Technology (EAT) exhibition that toured the United States in 1966. These event-exhibitions marked a rare confluence of technology-enabled art practice that resonated profoundly with cultural movements of the 1960s.

Artists and intellectuals of the early Soviet era were inspired not only by the expressive possibilities of cinema but also by the science of statistics and Darwinian evolution as tools for understanding and predicting the behaviour of complex systems over extended periods of time. By contrast, many of today's most provocative art practices and models of cultural critique respond to or make use of information systems generated by large-scale data tracking and aggregation. Although the specificity of human perceptions and desires is eclipsed by their function as source data, our ability to understand, critique and ultimately disrupt prevailing systems of economic and political power may well depend on our ability to recognize the kind of holistically integrated systems that are rendered visible through the conjunction of art and technology.

\section{Commentary by Nadezda Grigoryeva}

The holistic aspect of theory building is essential for the epoch of the 1920s. From this perspective, it is especially interesting that Pia Tikka traces the influence of Alexander Bogdanov's universal science of organization on Sergei Eisenstein's montage theory and systemic approach to cinema. Tikka puts both thinkers in a wider context of the 1920s and makes clear that such forms of holistic thought as tektology and montage are representative for the cultural space of Soviet Russia. The researcher takes into consideration a lot of examples of systemic thinking, such as Alexei Gastev's 'scientific organization of work' (see Gastev 1921), Alexei Gan's 'Constructivism' (1922), Sergei Tretyakov's 'Perspectives of Futurism' (1923), Dziga Vertov's film theory and so on. 
In addition, I would like to suggest another tektological parallel to Eisenstein's concept of montage. Bogdanov's tektology can be viewed as part of the Russian philosophical movement, which was initiated by Nikolai Fedorov's 'Philosophy of the Common Task'. In his work, Fedorov planned the resurrection of the dead with scientific methods. This idea was important for Bogdanov's universal science of organization: In anticipation of its own resurrection, mankind had to rejuvenate itself and struggle with the 'tektological disease' of ageing. Bogdanov saw the means of this struggle in the reciprocal blood transfusion which was to increase the vitality of sharing organisms. The philosopher Valerian Muravyev echoed Bogdanov's ideas in his philosophical tractate 'Mastering the Time as the Main Labour Organization Task' (1924). Time overall and human time in particular were reversible for Muravyev, because all things for him consisted of mathematical combinations of elements that could be changed to the previous station. For example, he describes physical experiments of 'resurrecting water'. Muravyev does not mention film in his writings, but time reversal through film editing can be traced in Soviet cinema of the 1920s: so, Dziga Vertov demonstrated time-reversed resurrection of the bull by means of reverse motion montage in his film Kino-Eye (1924).

I would assume that the idea of film montage as tektological mastering of time was essential for filmmakers of the 1920s, whether it was Vertov or Eisenstein. Film editing has been influenced by tektology, and cinematography has made contributions to utopian dreams of human reawakening. According to Vyacheslav Ivanov, Eisenstein often pursued the task of 'reanimating fossilized images' (Ivanov 1976: 163) in his films. The film director brought motionless symbols out of stasis and demonstrated montage sequences which shared life to static objects and, as a transition to Eisenstein's mature synthetic theory, put them into 'ex-stasis'.

\section{References}

Arsenjuk, L. 2018. Movement, Action, Image, Montage: Sergei Eisenstein and the Cinema in Crisis, 194-198. Minneapolis: Minnesota University Press.

Alekseeva, G. 1998. "Bogdanov and the development of science in the twentieth century". In Alexander Bogdanov and the origins of systems thinking in Russia, eds. Biggart, J., Dudley, P., and King, F., 15-24.

Aumont, J. 1987. Montage Eisenstein. London: BFI Publishing \& Bloomington and Indianapolis: Indiana University Press.

Bertalanffy, L. von. 1968. General System Theory: Foundations, Development, Applications. New York: George Braziller Inc.

Biggart, J. and Bulgakowa, O. 2021. "Eisenstein in the Proletkult". Cultural Science Journal, 13.

Biggart, J.; Dudley, P. and King, F. eds. 1998. Alexander Bogdanov and the origins of systems thinking in Russia. UK: Ipswich Book Company \& Ashgate Publishing Company.

Bogdanov, A. 1980. Essays in Tektology: The General Science of Organization. Trans. George Gorelik. Seaside, CA, Intersystems Publications.

Bogdanov, A. 1924. "The Workers' Artistic Inheritance". The Labour Monthly, September 1924, 549-597. Transcribed by Ted Crawford and Adam Buick. Proofread by Jay Blackwood. Creative Commons, marxists.org 2004.

Bogdanov, A. 1918/1924. "Nauka i rabochii klass", 1918; reprinted in O proletarskoi kul'ture, 19041924, Moscow, 1924: 200-221, quotation p. 208. (Recited in Mally 1990: 162).

Bohn, A. 2003. Film und Macht: Zur Kunsttheorie Sergej M. Eisensteins 1930-1948. Diskurs Film Verlag Schaudig \& Ledig GbR. 
Bordwell, D. 1993. The Cinema of Eisenstein. Harvard University Press.

Bulgakowa, O. 2021. "Eisenstein's system thinking: Influences and inspirations". Cultural Science Journal, 13.

Bulgakowa, O. 1998. Sergei Eisenstein. A Biography. Berlin \& San Francisco: Potemkin Press.

Bulgakowa, O.1996. Sergej Eisenstein - drei Utopien. Architekturentwürfe zur Filmtheorie. Berlin: Potemkin Press.

Cassirer, E. 1950. The Problem of Knowledge: Philosophy, Science, and History since Hegel. New have: Yale University Press.

Chehonadskih, M. 2018. "The Stofflichkeit of the Universe: Alexander Bogdanov and the Soviet Avant-Garde". E-flux online journal, \#88. https://www.e-flux.com/journal/88/174279/the-stofflichkeit-of-the-universe-alexander-bogdanov-and-the-soviet-avant-garde/

Christie, I. and Vassilieva, J. (eds) 2021. The Eisenstein Universe. UK: Bloomsbury Academic.

Chuzhak, NF. 1923. "Under the Sign of Life-Building: How to Perceive Today's Art". LEF 1:12-39. Moscow and Petrograd. (Cited in Ogurtsov 1998: 264 n. 23).

Eisenstein, SM. 2006. The Eisenstein Collection: Sergei Eisenstein. Ed. Richard Taylor. London, New York, and Calcutta: Seagull Books.

Eisenstein, SM. 1996. Writings 1934-47. Selected Works. Vol. 3. Ed. Richard Taylor, transl. William Powell. London: BFI Publishing.

Eisenstein, SM. 1991. Towards a Theory of Montage 1937-40. Selected Works. Vol. 2. Ed. Michael Glenny \& Richard Taylor. London: BFI Publishing.

Eisenstein, SM. 1988. Writings 1922-34. Selected Works. Vol. 1. Ed. and trans. Richard Taylor. London: BFI Publishing.

Eisenstein, SM. 1988a. Das dynamische Quadrat. Schriften zum Film. Eds. Oksana Bulgakova and Dietmar Hochmuth. Leipzig, Reclam.

Eisenstein, SM. 1987. Nonindifferent Nature: Film and the Structure of the Things. Cambridge: Cambridge University Press.

Eisenstein, SM. 1943. The Film Sense. Ed. Jay Leyda. London: Faber and Faber Ltd.

Eisenstein, SM. 1923. "Montazh atraktsionov [Montage of attractions]". LEF 3 (1923): 70-75.

Fedorov, NF. 1990. What Was Man Created For? The Philosophy of the Common Task. London: Honeyglen.

Gan, AM. 1922. Konstruktivizm. Tver': Tverskoe izdatel'stvo.

Gastev, AK. 1921. Nashi zadachi. Moskva: Institut truda.

Gloveli, G. 1998. "Psychological applications of Tektology". In: Alexander Bogdanov and the origins of systems thinking in Russia, eds. John Biggart, Dudley, P., and King, F., 88-95. UK: Ipswich Book Company \& Ashgate Publishing Company.

Gloveli, G. 1998a. "Bogdanov as Scientist and Utopian". In: Bogdanov and His Work: A Guide to the Published and Unpublished Works of Alexander A. Bogdanov (Malinovsky) 1873-1928, eds. John Biggart, Georgii Gloveli, and Avraham Yassour, 40-59. Aldershot, England Brookfield: Ashgate Publishing.

Golomstock, I. 1990. Totalitarian Art. New York: Harper Collins Publishers, 26. (Cited in Manovich 1993: 22)

Grossi, EG. 1999. "Eisenstein as theoretician: preliminary considerations". In Eisenstein rediscovered, eds. Ian Christie and Richard Taylor, 167-176. London and New York: Routledge.

Ivanov, VV. 1976. Ocherki po istorii semiotiki v SSSR. Moskva: Nauka.

Kleiman, N. 2007. Personal Communication.

Lee, L-H.; Braud, T.; Zhou, P.; Wang, L.; Xu, D.; Lin, Z.; Kumar, A.; Bermejo, C. and Hui, P. 2021. "All One Needs to Know about Metaverse: A Complete Survey on Technological Singularity, Virtual Ecosystem, and Research Agenda. ArXiv, abs/2110.05352. 
Manovich, L. 1993. The Engineering of Vision from Constructivism to Computer. Ph.D. Dissertation, Visual and Cultural Studies, University of Rochester. URL (1/2008): http://www.manovich.net/EV/ ev.pdf.

Mally, L. 1990. Culture of the Future: The Proletkult Movement in Revolutionary Russia. Berkeley: University of California Press. http://ark.cdlib.org/ark:/13030/ft6m3nb4b2/

Maturana, H. and Varela, F. 1980. Autopoiesis and Cognition: The Realization of the Living. Vol. 42: Boston Studies in the Philosophy of Science, eds. Robert S. Cohen \& Marx W. Wartofsky [1st edition 1973]. Dordecht: D. Reidel Publishing Co.

Meyerhold, V. 1981. Teatterin Lokakuu [A Revolution in the theatre]. Helsinki: Love Kirjat.

Moiseev, N. 1998. "Tektology in contemporary perspective". In Alexander Bogdanov and the origins of systems thinking in Russia, eds. John Biggart, Dudley, P., and King, F., 221-227.

Muravyev, V. 1998. Mastery over Time: Selected works philosophical and publicistic works. Moscow: ROSSPEN. (in Russian).

Muravyev, VN. 2011. Sochineniia. Vol. 2. Moskva: IMLI RAN.

Nesbet, A. 2003. Savage Junctures: Sergei Eisenstein and the Shape of Thinking. London \& New York: I. B. Tauris.

Ogurtsov, A. 1998. "Bogdanov and the idea of co-evolution". In Alexander Bogdanov and the origins of systems thinking in Russia, eds. John Biggart, Dudley, P., and King, F., 254-264.

Oittinen, V. 2021. "Aleksandr Bogdanov and V. I. Lenin On 'things-In-Themselves"'. Cultural Science Journal, 13

Olenina, AH. 2020. Psychomotor Aesthetics: Movement and Affect in Modern Literature and Film. New York: Oxford UP.

Petitot, J.; Varela, FJ.; Pachoud, B. and Roy, J-M. (eds.) 1999. Naturalizing Phenomenology: Issues in Contemporary Phenomenology and Cognitive Science. Stanford, CA: Stanford University Press.

Petric, V. 1987. Constructivism in Film: The Man with the Movie Camera: A Cinematic Analysis. Cambridge University Press.

Pollmann, I. 2018. Cinematic Vitalism: Film Theory and the Question of Life. Film Theory in Media History. Amsterdam: Amsterdam University Press. https://www.degruyter.com/document/ doi/10.1515/9789048534005-003/html.

Popkov, VV. 1998. Alexander Bogdanov As Scientist And Revolutionary. Online International A. Bogdanov Institute, Library of Congress Catalog Card Number: 98-77890. URL (1/2008): http://www.bogdinst.ru/bogdanov/popkov2.htm.

Poustilnik, S. 2021. "Aleksandr Bogdanov's Tektology: A proletarian science of construction". Cultural Science Journal, 13.

Poustilnik, S. 1998. "Biological ideas in Tektology". In Alexander Bogdanov and the origins of systems thinking in Russia, eds. Biggart, J., Dudley, P., and King, F., 63-73.

Segal, D. 1974. Aspects of Structuralism in Soviet Philology. Papers on Poetics and Semiotics 2. Online version available in URL (5/2008): http://www.tau.ac.il/tarbut/pubtexts/segal/135. Tel-Aviv: Tel-Aviv University.

Seton, M. 1978. Sergei M. Eisenstein: A Biography. Revised edition. (First published 1953). London: Dennis Dobson.

Somaini, A. 2011. Ejzenstejn. I/ cinema, le arti, il montaggio (Eisenstein. Cinema, the Arts, Montage): Torino: Piccola Biblioteca Einaudi.

Susiluoto, I. 2006. Suuruuden laskuoppi: Venäläisen tietoyhteiskunnan synty ja kehitys. Helsinki: Werner Söderström Osakeyhtiö.

Susiluoto, I. 1982. The Origins and Development of Systems Thinking in the Soviet Union: Political and Philosophical Controversies from Bogdanov and Bukharin to Present-Day Re-Evaluations. AASF B Dissertation 30, Helsinki: Publication of Finnish Academy of Sciences. 
Taylor, B. 1991. Art and Literature under the Bolsheviks: the Crisis of Renewal 1917-1924, vol 1. London: Pluto Press.

Taylor, FW. 1911. The Principles of Scientific Management. New York: Harper. (Cited in Manovich 1993).

Tikka, P. 2009. "Tracing Tectology in Sergei Eisenstein's Holistic Thinking". In Alexander Bogdanov Revisited, Aleksanteri Series 1:2009, ed. V. Oittinen, 211-234. Helsinki: Gummerus Printing.

Tikka, P. 2008. Enactive Cinema: Simulatorium Eisensteinense. PhD diss. Helsinki: University of Art and Design Publication Series.

Tretyakov, S. 1923." Otkuda i kuda?" (Perspektivu futurizma). In LEF 1 (1923): 192-213.

Waite, C. 2021. "Somatic Montage for Immersive Cinema". Cultural Science Journal, 13.

White, J. 1998, "Sources and precursors of Bogdanov's Tektology". In: Alexander Bogdanov and the origins of systems thinking in Russia, eds. John Biggart, Dudley, P., and King, F., 25-42

White, J. 2018. Red Hamlet. The Life and Ideas of Alexander Bogdanov. Leiden: Brill.

Wiener, N. 1948. Cybernetics or Control and Communication in the Animal and the Machine. Hermann Editions in Paris; Cambridge: MIT Press, Wiley \& Sons in NY.

\section{Authors information}

Dr Pia Tikka is a filmmaker and EU Mobilitas Research Professor at the Baltic Film, Media, and Arts School, Tallinn University. She is a founder of NeuroCine, a research group that studies the neural basis of storytelling. She has published widely on the topics of enactive media, narrative complex systems, and neurocinematics. She is a Fellow of the Society for Cognitive Studies of the Moving Image and a member of the European Film Academy, and her filmography includes international productions. She has directed two fiction films - Daughters of Yemanjá (1996) and Sand Bride (1998) - as well as music videos, interactive films and VR films. Currently, she leads the Enactive Virtuality Lab at Tallinn University to explore the human experience of co-presence with humanlike artificial agents in immersive narrative contexts.

Steve F. Anderson is Professor of Film, Television \& Digital Media and Design Media Arts at UCLA. He is the author of Technologies of Vision: The War Between Data and Images (2017) and Technologies of History: Visual Media and the Eccentricity of the Past (2011), and co-editor of the anthology Reclaiming Popular Documentary (2021). He is a scholar-practitioner working at the intersections of media, technology and history.

Nadezda Grigoryeva, PhD in philology (2004), PhD in philosophy (2009), is a lecturer at the Faculty of Philosophy, Slavic Department of Eberhard Karls University of Tübingen (Germany). She is the author of many works on Russian literature and philosophy, philosophical anthropology and media studies. She has published books including Anima laborans: Writers and work in Russia in the 1920s-30s (2005) and Human, Inhuman: Radical Anthropology in Philosophy, Literature and Cinema of the Late 1920s-1950s (2012)

\section{○ \\ OPEN ACCESS}

Copyright: $\odot 2021$ The Author(s). This is an open-access article distributed under the terms of the CreativeCommons Attribution 4.0 International License (CC-BY 4.0), which permits unrestricted use, distribution, andreproduction in any medium, provided the original author and source are credited. See http://creativecommons.org/licenses/by/4.0/. 